\title{
IMPACTS OF WET AND DRY PERIODS ON LEAF GAS EXCHANGE, WATER USE EFFICIENCY AND CARBON ISOTOPE DISCRIMINATION IN DIFFERENT OIL PALM MATERIALS
}

\begin{abstract}
A'FIFAH, A $\mathrm{R}^{\star}$ and HANIFF, $\mathrm{M} \mathrm{H}^{\star}$
ABSTRACT

This study was conducted to investigate the effects of two different periods (i.e wet and dry) and five different oil palm materials [i.e. tenera (DxP) and clonal palms (i.e. PL68, PL104, PL106 and PL127)] on leaf carbon isotope discrimination $(\Delta)$, leaf gas exchange parameters such as net photosynthesis $\left(P_{N}\right)$, stomatal conductance $\left(g_{s}\right)$, transpiration rate $\left.\left(T_{r}\right)\right)$, intercellular $\mathrm{CO}_{2}$ concentration (ci) and instantaneous water use efficiency (WUE) and their relationships, in different oil palm materials cultivated on peat. Leaf gas exchange of 8-year old DxP and clonal palms were determined during dry and wet periods which were also analysed for leaf $\Delta$. Results showed that there were significant differences in $P_{N^{\prime}} g_{s}$ and $T_{r}$ between different periods. The $g_{s}$ values decreased by $54 \%$ during dry period compared to the wet period. This reduction in $g_{s}$ led to a reduction of $59 \%$ and $44 \%$ in $P_{N}$ and $T_{r}$, respectively. The interaction effect between oil palm materials and different periods had a significant influence on the leaf $\Delta$ values. Leaf $\Delta$ in clonal palm PL106 was less discriminated (23.74 $\pm 0.42 \%$ ) compared to the $D \times P$ palm during dry season (27.92 $\pm 0.70 \%$ o). A negative relationship was observed between leaf $\Delta$ with instantaneous WUE and leaf $\Delta$ was found to be highly correlated with $c_{i}$ in oil palm during the wet period.
\end{abstract}

Keywords: leaf gas exchange, water use efficiency, carbon isotope discrimination

Date received: 14 March 2018; Sent for revision: 16 March 2018; Received in final form: 17 July 2018; Accepted: 22 October 2018.

\section{INTRODUCTION}

Oil palm has become an increasingly attractive crop in the last few decades to meet the world's demand for oils and fats as it is able to produce up to 10 times more oil than in other oilseed crops in 1 ha of oil palm plantation (Lamade et al., 2016). In Malaysia, the oil palm planted areas in 2016 reached 5.74 million hectares, an increase of only $1.74 \%$ against the 5.64 million hectares recorded in 2015, mainly due to the increase in new planted areas in Sarawak (Kushairi et al., 2018).

\footnotetext{
Malaysian Palm Oil Board, 6 Persiaran Institusi Bandar Baru Bangi, 43000 Kajang,

Selangor, Malaysia.

E-mail: afifah@mpob.gov.my
}

The oil palm yield potential is affected when palms are exposed to stress conditions such as low moisture condition. The critical moisture stress periods for oil palm are 24 months, 18 months and five months prior to fruit maturation of the fruit bunches (Haniff et al., 2010). If palms are subjected to water stress during the 24 months before fruit maturation, it will lead to a higher proportion of male inflorescences. Eighteen months before fruit maturation is the time of inflorescence abortion. If oil palm are subjected to water stress, fewer female inflorescence would be developed and smaller fruit bunches will be produced. Pollination is important in oil palm to ensure high fruitset and successful fruit bunch development. Pollination occurs five months before fruit maturity. If palms are 
subjected to heavy rainfall during pollination less pollination occurs and will affect the quality of fresh fruit bunches harvested (Haniff et al., 2010). The increasing probability of seasonal droughts (Easterling et al., 2000; Seneviratne et al., 2010) and extreme rainfall emphasises the significance oftraits such as water use efficiency (WUE) and drought tolerance fall under the selection criteria of oil palm production to alleviate the potential negative effects of future climate change (King et al., 2013).

WUE is defined as plant dry matter production per unit of water loss through transpiration at the whole-plant level (Broeckx et al., 2014). At the leaf level, instantaneous WUE of leaf gas exchange is the basic unit of production which could be moles of carbon gained in photosynthesis $\left(P_{N}\right)$ in exchange for water used in transpiration $\left(T_{r}\right)$ (Farquhar et al., 1989). A similar parameter called intrinsic WUE, is defined as the ratio of $P_{n}$ and stomatal conductance $\left(g_{s}\right)$ (Erice et al., 2007; Choi et al., 2007; Ali and Talukder, 2008; Qiu et al., 2008).

The $P_{N}$ activity in the leaf is an integral process that depends on many biochemical reactions (Taiz and Zeiger, 2006). Water is an important factor for biochemical process in $P_{N}$. Stomatal closure is the primary diffusive limitation to $P_{N}$ and one of the earliest responses to drought during the growing season (Wilson et al., 2000; Chaves et al., 2002; Flexas and Medrano, 2002). The $P_{N}$ is inhibited during the dry period associated with the stomatal closure in oil palm under field condition due to changes in the saturation deficit of air and reduction in $T$, (Dufrene and Saugier, 1993; Lamade and Setiyo, 1996; Bayona-Rodriguez et al., 2016). Oil palm stomata will close early in the dry period and remain closed for a short period that can vary for several weeks depending on the level of drought severity (Villlobos et al., 1991). In the wet period, oil palm stomata open early in the morning and remain wide open throughout the day before closing in the early evening (Rees, 1961). A recent finding reported by Bayona-Rodriguez et al. (2016) found that a significant difference in photosynthetic behaviour among different measurement periods (i.e. dry, transition and wet) in oil palm under field condition in Columbia. Higher WUE indicates that plant uses the water efficiently for $P_{N}$. Many studies have been done to investigate the gas exchange and WUE of oil palm seedlings under water deficit and drought stress condition (Suresh et al., 2010; Rivera et al., 2012; 2016; Jazayeri et al., 2015; Rivera et al., 2016; Silva et al., 2017). However, information on WUE of oil palm under field condition at different period is very limited. Previous studies reported that different species of oil palm respond differently to three different periods (i.e. wet, transition and dry). E. guineensis had a lower WUE during wet period than in dry period. However, WUE of interspecific hybrid (E. oleifera $x$ E. guineensis) was found to have no difference among periods (Bayona-Rodriguez et al., 2016). Many research have been done to explore physiological traits that can be substitute to WUE measurement. The current measurement of WUE at the level could be determined using photosynthetic gas exchange but this method is laborious and unreliable method for long-term WUE (Johnson and Rumbaugh, 1995; Canavar et al., 2014).

Carbon isotope composition $\left({ }^{13} \mathrm{C}\right)$ of plant organic material varies among different types of plants and among plants grown in different environments (Nier and Gulbransen, 1939; Wickman, 1952). Discrimination against the naturally stable isotope ${ }^{13} \mathrm{C}$ occurs during photosynthetic $\mathrm{CO}_{2}$ fixation and this is reflected in the $\delta^{13} \mathrm{C}$ of plant tissue (Farquhar et al., 1989). In $C_{3}$ plants, discrimination is largely dependent on the ratio between the concentration of $\mathrm{CO}_{2}$ in the leaf intercellular space and that of ambient air $\left(\mathrm{C}_{\mathrm{i}} / \mathrm{C}_{\mathrm{a}}\right)$ prevailing when the leaf carbon is assimilated. This ratio represents a balance between the rates of inward $\mathrm{CO}_{2}$ diffusion controlled by stomatal conductance and $\mathrm{CO}_{2}$ assimilation determined by photosynthesis (Farquhar et al., 1982; 1989; Evans et al., 1986).

Carbon isotope discrimination $(\Delta)$ could reduce time required for WUE measurement in plants. It has been used as an integrated measure of photosynthetic gas exchange to evaluate changes in environmental conditions. It also provides a long-term average estimate of $C_{i} / C_{a}$ as a plant metabolism indicator (Farquhar et al., 1982; 1989; Farquhar and Richard, 1984) and could be used as a comparative measure of instantaneous water use efficiency WUE and long-term transpiration efficiencies among species (Farquhar et al., 1989). Carbon isotope discrimination $(\Delta)$ is a physiological trait that is related to WUE. The $\Delta$ is expected to be negatively correlated with WUE (Farquhar and Richards, 1984). Previous studies demonstrated that $\Delta$ value correlated with the WUE in Coffea species (Meinzer et al., 1990; 1991) but no documentation on relationship between WUE and $\Delta$ of oil palm is reported.

The seasonal changes of $P_{N^{\prime}} T_{r}$ and WUE are important for plant production. Zona et al. (2012) reported that seasonal variability in $P_{\mathrm{N}}$ is a strong determinant of carbon-balance. Changes in climatic factors, such as rainfall and fluctuations in water availability, influence the yield of plants such as oil palm. Broeckx et al. (2014) suggested that the seasonal changes in $\Delta$ with $P_{N}$ as a potential indicator of WUE provide a detailed field conditions of different water availability. However, information on gas exchange, instantaneous WUE and $\Delta$ in oil palm under different periods are limited. In this study, we evaluated the effects of periods and oil palm materials on leaf gas exchange, instantaneous WUE and $\Delta$. 


\section{MATERIALS AND METHODS}

\section{Experimental Design and Planting Materials}

The study was conducted at an oil palm plantation in Perak, Malaysia $101^{\circ} 05^{\prime} 22.248^{\prime \prime} \mathrm{E}$ $3^{\circ} 49^{\prime} 09.167^{\prime \prime} \mathrm{N}$. Oil palm planting materials including commercial tenera, DxP and clonal palms (i.e. PL68, PL104, PL106, and PL127) were selected for this study. The oil palm planting materials were planted on shallow peat at a density of 136 palm ha $^{-1}$ in December 2007. Assessment was performed over four palms on each oil palm material between 17- 26 November 2015 (wet period) and on 9-19 August 2016 (dry period). The monthly rainfall and number of rainy days in 2015 and 2016 are given in Figure 1 and Table 1, respectively. The experiment was carried out in a randomised complete block design with two factors (i.e. planting material and period) and four replications. The oil palm was about 8-year old when the measurements were taken.

\section{Leaf Gas Exchange Measurement}

Leaf gas exchange parameters were measured on intact leaflets attached to frond 17 of oil palm materials with a portable photosynthesis system
(Model LI-6400XT, LI-COR, Inc., USA) together with the following benchmark parameters: 400 ppm $\mathrm{CO}_{2}$ and $1000 \mu \mathrm{mol} \mathrm{m} \mathrm{m}^{-2} \mathrm{~s}^{-1}$ PAR radiation. Gas exchange parameters such as $P_{N}, g_{s} C_{i}$ and $T_{r}$ rate were measured between 8:30 and 11:30 hr. Leaf temperature $\left(T_{L}\right)$ is measured with a thermistor and instantaneous WUE was calculated as $P_{N} / T_{r}$. During the measurements, the ambient air temperature was $30.27^{\circ} \mathrm{C}$ and $30.51^{\circ} \mathrm{C}$ and leaf temperature was about $30.54^{\circ} \mathrm{C}$ and $31.11^{\circ} \mathrm{C}$ in the wet and dry periods, respectively. The ambient air humidity was $78.38 \%$ in the dry periods. However, air humidity data was not available in the wet period due to some other technical reason.

\section{Chlorophyll Fluorescence Measurement}

Chlorophyll fluorescence parameters were measured on intact leaflets attached to frond 17 of oil palm materials with Plant Efficiency Analyser (Pocket PEA, Hansatech, Instrument Ltd, England) for both measurement periods. Before measurement was done, oil palm leaflets were dark adapted for $15 \mathrm{~min}$ by attaching light-exclusion clips to the leaf surface then initial fluoresence $\left(F_{0}\right)$, variable fluorescence $\left(F_{v}\right)$, maximum fluorescence $\left(F_{m}\right)$, efficiency of the water-splitting complex on the

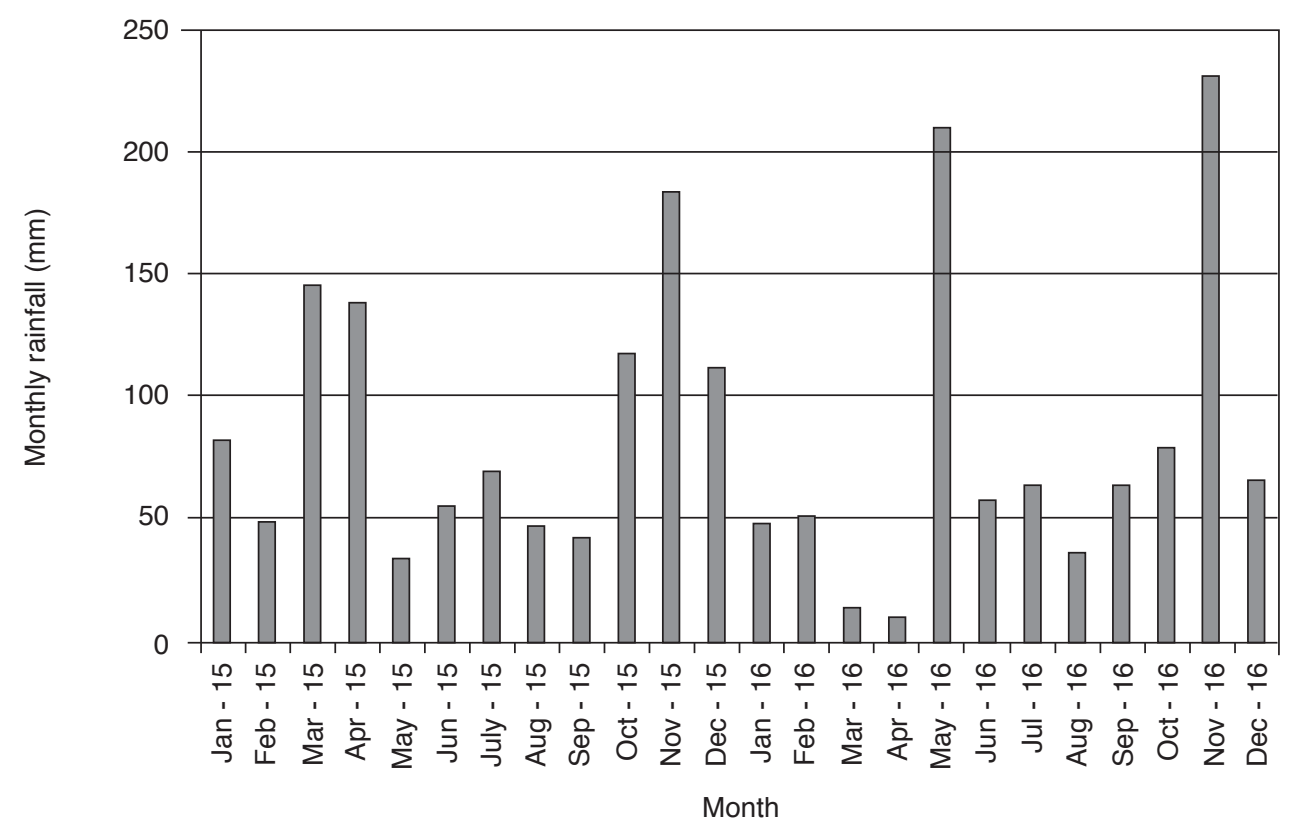

Figure 1. Monthly rainfall of oil palm plantation in Teluk Intan, Perak, Malaysia from January 2015 to December 2016.

TABLE 1. NO. OF RAINY DAYS AT OIL PALM PLANTATION IN TELUK INTAN, PERAK, MALAYSIA FROM JANUARY 2015 TO DECEMBER 2016

\begin{tabular}{|c|c|c|c|c|c|c|c|c|c|c|c|c|}
\hline Year & \multicolumn{11}{|c|}{ Month } & Dec \\
\hline 2015 & 7 & 1 & 14 & 18 & 5 & 4 & 5 & 7 & 8 & 14 & 17 & 12 \\
\hline 2016 & 8 & 7 & 3 & 2 & 11 & 2 & 7 & 6 & 5 & 8 & 13 & 9 \\
\hline
\end{tabular}


donor side of PSII $\left(F_{v} / F_{o}\right)$, quantum yield of PSII $\left(F_{v} / F_{m}\right)$ and performance index $(\mathrm{PI})$ were determined.

\section{Carbon Isotope Discrimination Determination}

The ${ }^{13} \delta \mathrm{C}$ was determined from the leaflets previously measured for leaf gas exchange. Leaf samples were oven dried at $70^{\circ} \mathrm{C}$ for $48 \mathrm{hr}$ and ground to a fine powder. The relative abundance of ${ }^{13} \mathrm{C}$ and ${ }^{12} \mathrm{C}$ in the $\mathrm{CO}_{2}$ produced in the leaf was determined using an Isotopic Ratio Mass Spectrometer at the Malaysian Institute of Nuclear Technology. Results were expressed as $\delta^{13} \mathrm{C}(\%)$ using the equation given below (Farquhar et al., 1989):

$$
\delta^{13} C(\% o)=\left[\frac{R_{p}}{R_{s}}-1\right] \times 1000 \quad \text { Equation (1) }
$$

where $R_{p}$ is the ${ }^{13} \mathrm{C} /{ }^{12} \mathrm{C}$ ratio measured in the planting material and $R_{s}$ is the ${ }^{13} \mathrm{C} /{ }^{12} \mathrm{C}$ ratio in the standard. The unit is expressed as part per thousand $(\%)$. A secondary standard calibrated against Pee Dee Belemnite (PDB) carbonate was used for comparison. The following formula was used to calculate the leaf $\Delta$ value (Farquhar et al., 1989):

$$
\Delta(\% o)=\frac{\delta_{a}-\delta_{\mathrm{p}}}{1-\delta_{\mathrm{p}}} \times 1000
$$

Equation (2)

where $\delta_{p}$ is the $\delta^{13} C$ of the sample and $\delta_{a}$ is the $\delta^{13} \mathrm{C}$ of atmospheric $\mathrm{CO}_{2}$. On the PDB scale, atmospheric $\mathrm{CO}_{2}$ has a current deviation of approximately $-8 \%$ o (Farquhar et al., 1989).

\section{Statistical Analysis}

The data set was subjected to analyses of variance (ANOVA) and the differences between the means of treatments were compared using Duncan's Multiple Range Test (DMRT) $(\mathrm{P} \leq 0.05)$. Pearson correlation analysis $(\mathrm{P} \leq 0.05)$ was performed to test the significance between the parameters. The entire data were processed using SAS software package 9 (SAS Institute, 2002).

\section{RESULTS AND DISCUSSION}

Rainfall distribution during wet and dry periods show that oil palm might be under soil water deficit coincided during dry period (Figure 1 and Table 1). From the present study, it was observed that the different periods had influenced the leaf gas exchange parameters such as $P_{N}, g_{s}$ and $T_{r}$ of oil palm $(\mathrm{P} \leq 0.05$; Figures $2 a$ to $2 c)$. Photosynthetic rate (19.63 $\left.\mu \mathrm{mol} \mathrm{m} \mathrm{m}^{-2}\right), g_{s}\left(0.34 \mathrm{~mol} \mathrm{~m}^{-2} \mathrm{~s}^{-1}\right)$ and $T_{r}(4.01 \mathrm{mmol}$ $\mathrm{m}^{-2} \mathrm{~s}^{-1}$ ) were statistically higher in the wet period compared to the dry period. Higher photosynthetic rate in oil palm during wet period associated with the higher in $g_{s}$ and $T_{r}$ might be due to higher soil water content. A relatively high amount of rainfall received before measurement time influenced the (a)

Planting material $(\mathrm{PM})=\mathrm{ns}$

Period $(P)=$ *

$\mathrm{PM} \times \mathrm{P}=\mathrm{ns}$

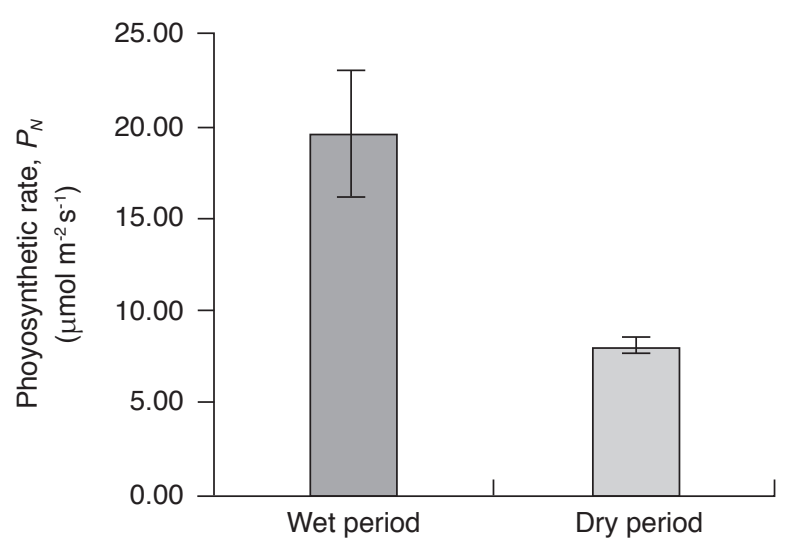

(b)

(c)

$$
\begin{aligned}
& \text { Planting material }(\mathrm{PM})=\mathrm{ns} \\
& \text { Period }(\mathrm{P})={ }^{*} \\
& \mathrm{PM} \times \mathrm{P}=\mathrm{ns}
\end{aligned}
$$

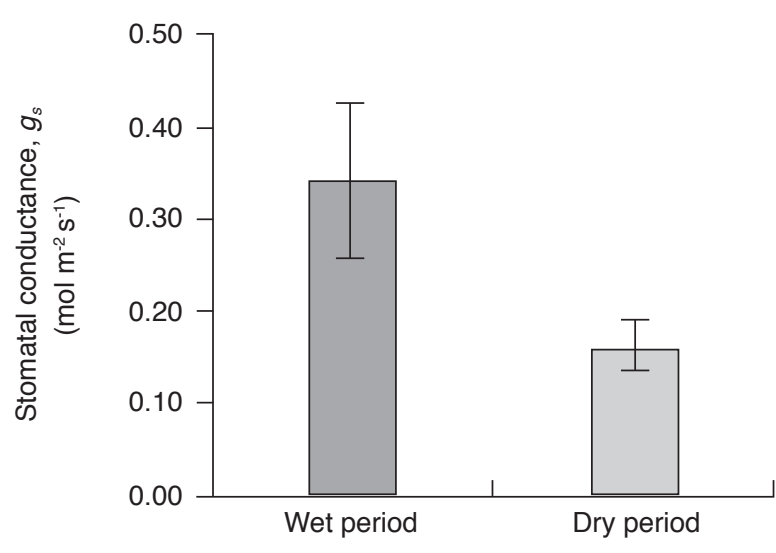

$$
\begin{aligned}
& \text { Planting material }(\mathrm{PM})=\mathrm{ns} \\
& \text { Period }(\mathrm{P})={ }^{\text {* }} \\
& \mathrm{PM} \times \mathrm{P}=\mathrm{ns}
\end{aligned}
$$

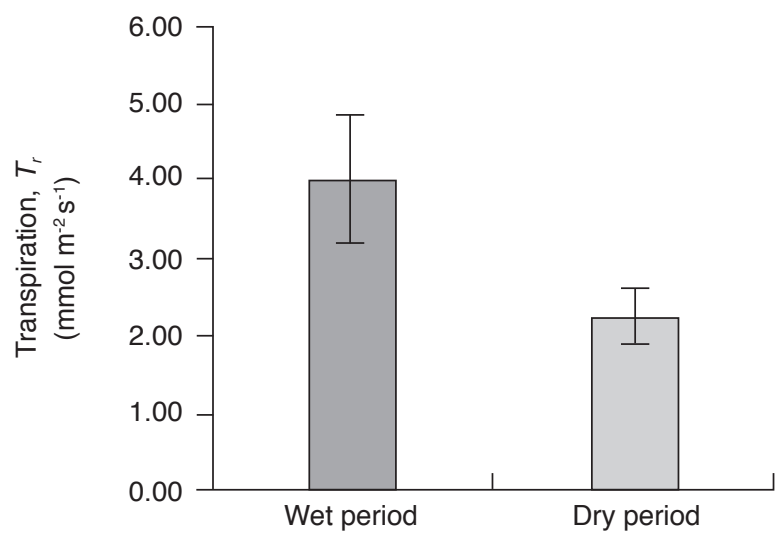

Figure 2. Photosynthetic rate (a), stomatal conductance (b) and transpiration rate (c) in oil palm cultivated on peat during wet and dry periods. Vertical bars represent \pm S.E of means of four replicates. ${ }^{*}$ Significant at $5 \%$ level and $n s=$ no significant $(P<0.05)$. 
high $\mathrm{CO}_{2}$ assimilation rate in oil palm. The $g_{s}$ values dropped about $54 \%$ during the dry period compared to the wet period. This reduction in $g_{s}$ led to a reduction of $59 \%$ and $44 \%$ in $P_{N}$ and $T$, respectively. A similar finding was reported by Bayona-Rodriguez et al. (2016) on oil palm grown under rain fed conditions. They discovered that significant gas exchange differences were found among the seasons in the field with no irrigation and gas exchanges were lower during dry season compared to the dry-to-wet transition and wet seasons. Other studies also found similar results in nursery plants under water deficit, in E. guineensis progenies (Jazayeri et al., 2015) and interspecific OxG hybrids (Rivera et al., 2013). Henson and Haniff (2005) confirmed that during the dry period, the most immediate response is the stomatal closure and thus, the reduction of the $T$ rates.

Leaf $\Delta$ wassignificantly influenced by interaction effects of periods and planting materials $(\mathrm{P} \leq 0.05$; Figure 3). Results showed that leaf $\Delta$ in five oil palm planting materials did not respond in the same way during both wet and dry periods. Leaf $\Delta$ in DxP and clonal palms (i.e. PL68, PL194 and PL106) during wet period and were less discriminated compared to the dry period. Low in $g_{s}$ and $P_{N}$ had contributed to a relatively high leaf $\Delta$ values in oil palm materials during the dry period. This result is not in agreement with the other findings by Nunes et al. (2016) on eucalypt clones. They reported that lower leaf $\Delta$ in the eucalyp tolerant clone with lower $g_{s}$ indicates a better stomata control while maintaining the photosynthetic rate for greater efficiency in the use of water. The differences between planting materials in leaf $\Delta$ was observed during the dry period. Results showed that there were variation in leaf $\Delta$ values of all oil palm planting materials during the dry period and DxP and clonal PL68 palms tend to increase the value of leaf $\Delta$ during the dry season. Leaf $\Delta$ was less discriminated in the clonal palm, PL106 (24.05\%o) compared to the $\operatorname{DxP}(27.92 \%)$ palm during the dry season. The decrease in discrimination suggested that reduction in $g_{s}$ resulted in limiting the $P_{N^{\prime}}$ which could be due to a decline in soil water. The decline in $\Delta$ was found when wheat seedlings were exposed to increasing levels of soil strength which decreased in soil water (Masle and Farquhar, 1988). In the present study, not all oil palm planting materials responded in the same way to drier soil conditions, indicating substantial genotypic variations in the degree of this response. Similar responses were observed in two Coffea species genotypes (Meinzer et al., 1990).

Leaf $\Delta$ and instantaneous WUE in different oil palm materials were negatively correlated $(r=0.65$, $\mathrm{P}<0.05$ ) (Table 2) during wet period. Therefore, leaf $\Delta$ values in oil palm is decreased when there is an increased in instantaneous WUE. Increased WUE is associated with a decrease in $c_{i}$ as exhibited by a very significant correlation coefficient $(\mathrm{r}=0.99, \mathrm{P}<0.05)$ (Table 2). At the same time, the decrease in leaf $\Delta$ of oil palm under wet period might be due to the decrease in $c_{i}$ as exhibited by the significantly high value of correlation coefficient $(\mathrm{r}=0.64, \mathrm{P}<0.05)$ (Table 2). This result indicates that lower in $c_{i}$ could be a possible factor for lower in leaf $\Delta$ values in oil palm. Read and Farquhar (1991) also proposed that $\Delta$ is positively related to $c_{i}$. During dry period, no correlation was found between leaf $\Delta$ of oil palm material with leaf gas exchange and chlorophyll fluorescence parameters (Table 3). But increased in WUE of oil palm materials during dry period is associated with decrease in $g_{s^{\prime}} c_{i}$ and $T_{r}$ (Table 3).

\section{CONCLUSION}

In conclusion, results showed that leaf gas exchange such as $P_{N}, g_{s}$ and $T_{r}$ rate in oil palm were significantly affected by wet and dry periods. The

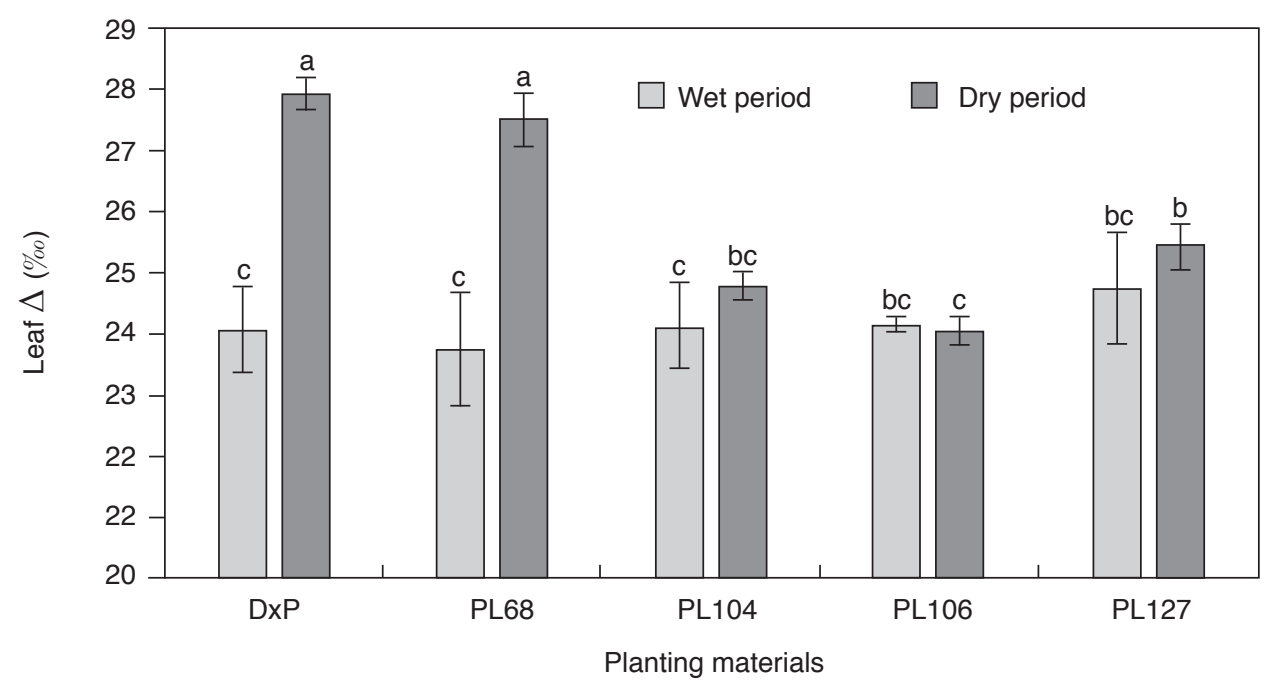

Figure 3. Interactive effects between periods and planting materials for leaf carbon isotope discrimination of oil palm. Vertical bars represent \pm S. E of means $(n=20)$. 
TABLE 2. CORRELATIONS BETWEEN LEAF CARBON ISOTOPE DISCRIMINATION ( $\triangle$ ), LEAF GAS EXCHANGE AND CHLOROPHYLL FLUORESENCE PARAMETERS AS WELL AS LEAF TEMPERATURE AMONG FIVE OIL PALM MATERIALS DURING WET PERIOD

\begin{tabular}{|c|c|c|c|c|c|c|c|c|c|c|c|c|c|}
\hline Parameters & $\boldsymbol{P}_{N}$ & $g_{s}$ & $c_{i}$ & $T_{r}$ & WUE & $\Delta$ & $F_{o}$ & $\boldsymbol{F}_{m}$ & $F_{v}$ & $F_{v} / F_{o}$ & $F_{v} / F_{m}$ & PI & $T_{L}$ \\
\hline$P N$ & 1.00 & - & - & - & - & - & - & - & - & - & - & - & - \\
\hline$g s$ & 0.12 & 1.00 & - & - & - & - & - & - & - & - & - & - & - \\
\hline$c i$ & $-0.60^{*}$ & $0.64^{*}$ & 1.00 & - & - & - & - & - & - & - & - & - & - \\
\hline $\operatorname{Tr}$ & 0.11 & $0.97^{*}$ & $0.66^{*}$ & 1.00 & - & - & - & - & - & - & - & - & - \\
\hline WUE & $0.64^{*}$ & $-0.60^{*}$ & $-0.99^{*}$ & $-0.64^{*}$ & 1.00 & - & - & - & - & - & - & - & - \\
\hline$\Delta$ & -0.29 & $0.53^{*}$ & $0.64^{*}$ & $0.63^{*}$ & $-0.65^{*}$ & 1.00 & - & - & - & - & - & - & - \\
\hline$F_{o}$ & 0.05 & -0.04 & -0.18 & -0.01 & 0.15 & 0.02 & 1.00 & - & - & - & - & - & - \\
\hline$F_{m}$ & -0.004 & 0.33 & 0.18 & 0.27 & -0.15 & 0.12 & $0.46^{*}$ & 1.00 & - & - & - & - & - \\
\hline $\mathrm{F}_{v}$ & -0.02 & 0.36 & 0.23 & 0.30 & -0.20 & 0.13 & 0.26 & $-0.98^{*}$ & 1.00 & - & - & - & - \\
\hline$F_{v} / F_{o}$ & -0.05 & 0.27 & 0.31 & 0.22 & -0.26 & 0.06 & $-0.54^{*}$ & $0.50^{*}$ & $0.66^{*}$ & 1.00 & - & - & - \\
\hline $\mathrm{F}_{v} / F_{m}$ & -0.04 & 0.35 & 0.35 & 0.31 & -0.30 & 0.11 & $-0.50^{*}$ & $0.53^{*}$ & $0.69^{*}$ & $0.97^{*}$ & 1.00 & - & - \\
\hline PI & 0.005 & -0.10 & 0.23 & 0.08 & -0.19 & 0.06 & $-0.75^{*}$ & 0.04 & 0.22 & $0.80^{*}$ & $0.70^{*}$ & 1.00 & - \\
\hline$T_{L}$ & -0.06 & -0.14 & -0.12 & -0.18 & 0.10 & 0.21 & 0.08 & -0.31 & -0.36 & -0.37 & -0.35 & -0.21 & 1.00 \\
\hline
\end{tabular}

Note: *Significant at $\mathrm{P} \leq 0.05 ., P_{N}$ - photosynthetic rate; $g_{s}$ - stomatal conductance; $c_{i}$ - intercellular $\mathrm{CO}_{2}$ concentration; $T_{r}$ - transpiration rate; WUE - instantaneous water use efficiency; $\Delta$ - leaf carbon isotope discrimination; $F_{o}$ - initial fluorescence; $F_{m}$ - maximum florescence; $F_{v}$ - variable fluorescence; $F_{v} / F_{o}$ - efficiency of the water-splitting complex on the donor side of PSII; $F_{v} / F_{m}$ - quantum yield of PSII; PI - performance index and $T_{L}$ - leaf temperature, *Significant at $5 \%$ level.

TABLE 3. CORRELATIONS BETWEEN LEAF CARBON ISOTOPE DISCRIMINATION ( $\triangle$ ), LEAF GAS EXCHANGE AND CHLOROPHYLL FLUORESENCE PARAMETERS AS WELL AS LEAF TEMPERATURE AMONG FIVE OIL PALM MATERIALS DURING DRY PERIOD

\begin{tabular}{|c|c|c|c|c|c|c|c|c|c|c|c|c|c|}
\hline Parameters & $\boldsymbol{P}_{N}$ & $g_{s}$ & $c_{i}$ & $T_{r}$ & WUE & $\Delta$ & $F_{o}$ & $F_{m}$ & $\boldsymbol{F}_{v}$ & $F_{\mathrm{v}} / F_{\mathrm{o}}$ & $F_{\mathrm{v}} / F_{\mathrm{m}}$ & $P I$ & $T_{\mathrm{L}}$ \\
\hline$P_{N}$ & 1.00 & - & - & - & - & - & - & - & - & - & - & - & - \\
\hline$g_{s}$ & $0.64^{*}$ & 1.00 & - & - & - & - & - & - & - & - & - & - & - \\
\hline$c_{i}$ & 0.10 & $0.73^{*}$ & 1.00 & - & - & - & - & - & - & - & - & - & - \\
\hline$T_{r}$ & $0.72^{*}$ & $0.98^{*}$ & $0.70^{*}$ & 1.00 & - & - & - & - & - & - & - & - & - \\
\hline WUE & 0.002 & $-0.70^{*}$ & $-0.98^{*}$ & $-0.65^{*}$ & 1.00 & - & - & - & - & - & - & - & - \\
\hline$\Delta$ & -0.02 & 0.01 & 0.08 & 0.08 & -0.11 & 1.00 & - & - & - & - & - & - & - \\
\hline$F_{o}$ & -0.36 & -0.21 & -0.11 & -0.29 & 0.06 & -0.21 & 1.00 & - & - & - & - & - & - \\
\hline$F_{m}$ & -0.23 & -0.29 & -0.20 & -0.33 & 0.20 & -0.21 & $0.77^{*}$ & 1.00 & - & - & - & - & - \\
\hline$F_{v}$ & -0.20 & -0.29 & -0.21 & -0.32 & 0.22 & -0.19 & $0.69^{*}$ & $0.99^{*}$ & 1.00 & - & - & - & - \\
\hline$F_{v} / F_{o}$ & 0.14 & -0.14 & -0.14 & -0.11 & 0.22 & -0.04 & -0.19 & $0.46^{*}$ & $0.57^{*}$ & 1.00 & - & - & - \\
\hline$F_{v} / F_{m}$ & 0.16 & -0.15 & -0.15 & -0.10 & 0.22 & 0.003 & -0.23 & 0.43 & $0.54^{*}$ & $0.99^{*}$ & 1.00 & - & - \\
\hline PI & 0.18 & -0.09 & -0.17 & -0.04 & 0.21 & 0.17 & -0.72 & -0.24 & -0.13 & $0.66^{*}$ & $0.67^{*}$ & 1.00 & - \\
\hline$T_{L}$ & -0.16 & -0.24 & -0.004 & -0.23 & 0.06 & -0.21 & 0.07 & -0.05 & -0.07 & -0.12 & -0.13 & -0.01 & 1.00 \\
\hline
\end{tabular}

Note: *Significant at $\mathrm{P} \leq 0.05 . P_{N}$ - photosynthetic rate; $g_{s}$ - stomatal conductance; $c_{i}$ - intercellular $\mathrm{CO}_{2}$ concentration; $T_{r}$ - transpiration rate; WUE - instantaneous water use efficiency; $\Delta$ - leaf carbon isotope discrimination; $F_{\mathrm{o}}$ - initial fluorescence; $F_{m}$ - maximum florescence; $F_{v}$ - variable fluorescence; $F_{v} / F_{o}$ - efficiency of the water-splitting complex on the donor side of PSII; $F_{v} / F_{m}$ - quantum yield of PSII; PI - performance index and $T_{L}$ - leaf temperature, *Significant at $5 \%$ level.

decline in leaf gas exchange in oil palm was more prominent during the dry period. The interaction effects between different periods and oil palm planting materials significantly affected the leaf $\Delta$. Leaf $\Delta$ is negatively correlated with instantaneous WUE during wet period and influenced by the intercellular $\mathrm{CO}_{2}$ concentration. We conclude that leaf $\Delta$ could be used as a rapid tool for assessing plant performance since it responded to different environment conditions. Further comprehensive studies on the seasonal leaf $\Delta$ of oil palm as well as during wet, transition and dry season are required to clarify the usefulness of leaf $\Delta$ as a substitute trait for evaluating plant response at various environmental conditions.

\section{ACKNOWLEDGEMENT}

We wish to thank the Director-General of MPOB for permission to publish this article. We also would like to thank the staff of Crop Physiology Group and Breeding and Tissue Culture Unit of Advanced Biotechnology and Breeding Centre, MPOB for their technical assistance and expertise in this project. 


\section{REFERENCES}

ALI, M H and TALUKDER, M S U (2008). Increasing water productivity in crop production - A synthesis. Agric Water Manage., 95: 1201-1213. http:// dx.doi:10.1016/j.agwat.2008.06.008

BLUM, A (2009). Effective use of water (EUW) and not water-use efficiency (WUE) is the target of crop yield improvement under drought stress. Field Crops Res., 112: 119-123. https:/ / doi.org/10.1016/j. fcr.2009.03.009

BAYONA-RODRIGUEZ, C J; OCHOA-CADAVID, I and ROMERO, H M (2016). Impacts of the dry season on the gas exchange of oil palm (Elaeis guineensis) and interspecific hybrid (Elaeis oleifera $\mathrm{x}$ Elaeis guineensis) progenies under field conditions in eastern Colombia. Agronomía Colombiana, 34: 329335. http:// dx.doi.org/10.15446/agron.colomb. v34n3.55565

BROECKX, L S; FICHOT, R; VERLINDEN, M S and CEULEMANS, R (2014). Seasonal variations in photosynthesis, intrinsic water-use efficiency and stable isotope composition of poplar leaves in a short-rotation plantation. Tree Physiol, 34: 701-715. https:// doi.org/10.1093/treephys/tpu057

CANAVAR, O; GOTZ, K P; ELLMER, F; CHMIELEWSKI, F M and KAYNAK, M A (2014). Determination of the relationship between water use efficiency, carbon isotope discrimination and proline in sunflower genotypes under drought stress. Aust. J. Crop Sci., 8: 232-242.

CHAVES, M M; PEREIRA, J S; MAROCO, J; RODRIGUES, M L; RICARDO, C P P; OSORIO, M L; CARVALHO, I; FARIA, T and PINHEIRO, C (2002). How plants cope with water stress in the field. Photosynthesis and growth. Ann. Bot., 89: 907-916. DOI:10.1093/aob/mcf105.

CHOI, W J; CHANG, S X and BHATTI, J S (2007). Drainage affects tree growth and $\mathrm{C}$ and $\mathrm{N}$ dynamics in a minerotrophic peatland. Ecology, 88: 443-453. DOI: 10.1890/0012-9658(2007)88[443:DATGAC]2.0. $\mathrm{CO} ; 2$.

DUFRENE, E and SAUGIER, B (1993). Gas exchange of oil palm in relation to light, vapour pressure deficit, temperature and leaf age. Funct. Ecology, 7: 97-104. DOI: $10.2307 / 2389872$.

EASTERLING, D P; MEEHL, G A; PARMESAN, C; CHANGNON, S A; KARL, T R and MEARNS, L $\mathrm{O}$ (2000). Climate extremes: Observations, modeling and impacts. Science, 289: 2068-2071. DOI: 10.1126/ science. 289.5487.2068.
ERICE, G; ARANJUELO, I; IRIGOYEN, J J and SANCHEZ-DIAZ, M (2007). Effect of elevated $\mathrm{CO}_{2}$, temperature and limited water supply on antixoxidant status during regrowth of nodulated alfafa. Physiol. Plant, 130: 33-45. http://dx.doi. org/10.1111/j.1399-3054.2007.00889.x

EVANS, J R; SHARKEY, T D; BERRY, J A and FARQUHAR, G D (1986). Carbon isotope discrimination measured concurrently with gas exchange to investigate $\mathrm{CO}_{2}$ diffusion in leaves of higher plants. Aust. J. Plant Physiol., 13: 281-292. DOI:10.1071/ PP9860281.

FARQUHAR, G D; BALL, M C; CAEMMERER, S VON and ROKSANDIC, Z (1982). Effect of salinity and humidity on $\delta^{13} \mathrm{C}$ value of halophytes evidence for diffusional isotope fractionation determined by the ratio of intercellular/atmospheric $\mathrm{CO}_{2}$ under different conditions. Oecologia, 52: 121-124. DOI: 10.1007 / BF00349020.

FARQUHAR, G D and RICHARDS, R A (1984). Isotope composition of plant carbon correlates with water use efficiency of wheat genotypes. Aust. J. Plant Physiol., 11: 539-552. https:// doi.org/10.1071/ PP9840539

FARQUHAR, G D; EHLERINGER, $\mathrm{J} \quad \mathrm{R}$ and HUBICK, K T (1989). Carbon isotope discrimination and photosynthesis. Annu. Rev. Plant Phys., 9: 121-137. https:// doi.org/10.1146/annurev. pp.40.060189.002443

FLEXAS, J and MEDRANO, H (2002). Energy dissipation in C3 plants under drought. Funct. Plant Biol., 29: 1209-1215. DOI: 10.1071/FP02015.

HANIFF, M H; AHMAD TARMIZI, M; MOHD ROSLAN, M N; KUSHAIRI, A; JUSOH, L; ABDUL RAHIM, A S and RAMLI, A (2010). Impact of $E l$ Nino occurrence on oil palm yield in Malaysia. The Planter, 86: 837-852.

HENSON, I E and HANIFF, M H (2005). The influence of climatic conditions on gas and energy exchanges above a young oil palm stand in North Kedah, Malaysia. J. Oil Palm Res. Vol. 17: 73-91.

JAZAYERI, S M; RIVERA, Y D; CAMPEROS-REYES, J E and ROMERO, H M (2015). Physiological effects of water deficit on two oil palm (Elaeis guineensis Jacq.) genotypes. Agron. Colombia, 33: 164-173. https:// doi.org/10.15446/agron.colomb.v33n2.49846

JOHNSON, D D and RUMBAUGH, M D (1995). Genetic variation and inheritance characteristics for carbon isotope discrimination in alfalfa. J. Range Manage., 48: 126-131. DOI: 10.2307/ 4002798. 
KING, J S; CLEULEMANS, R and ALBAUGH, J M (2013). The challenge of lignocellulosic bioenergy in a water-limited world. Bioscience, 63: 102-117. DOI:10.1525/bio.2013.63.2.6

KUSHAIRI, A; SOH KHEANG LOH; AZMAN, I; ELINA HISHAMUDDIN; MEILINA ONGABDULLAH; ZAINAL BIDIN MOHD NOOR IZUDDIN; RAZMAH, G; SHAMALA SUNDRAM and GHULAM KADIR AHMAD PARVEEZ (2018). Oil palm economic performance in Malaysia and R\&D progress in 2017. J. Oil Palm Res. Vol. 30(2): 163-195.

LAMADE, E; TCHERKEZ, G; DARLAN, N H; RODRIGUES, R L; FRESNEAU, C; MAUVE, C; LAMOTHE-SIBOLD, $\mathrm{M}$; SKETRIENÉ, $\mathrm{D}$ and GHASHGHAIE, J (2016). Natural ${ }^{13} \mathrm{C}$ distribution in oil palm (Elaeis guineensis Jacq.) and consequences for allocation pattern. Plant Cell Environ., 39: 199212. DOI: $10.1111 /$ pce.12606.

LAMADE, E and SETIYO, E (1996). Variation in maximum photosynthesis of oil palm in Indonesia: Comparison of three morphologically contrasting clones. Plantations, Recherche, Développement, 3: 429435.

MASLE, J and FARQUHAR, G D (1988). Effect of soil strength on the relation of water use efficiency and growth to carbon isotope discrimination in wheat seedlings. Plant Physiol., 86: 32-38.

MEINZER, F C; GOLDSTEIN, G and GRANTS, D A (1990). Carbon isotope discrimination in coffee genotypes grown under limited water supply. Plant Physiol., 92: 130-135.

MEINZER, F C; INGAMELLS, J L and CRISTOTO, C (1991). Carbon isotope discrimination correlates with bean yield of diverse coffee seedlings populations. HortSci., 26: 1413-1414.

NIER, A O and GULBRANSEN, E A (1939). Variations in the relative abundance of the carbon isotopes. J. Amer. Oil Chem. Soc. Vol. 61: 697-698. DOI: $10.1021 /$ ja01872a047.

NUNES, F N; BARROS, N F; DE NOVAIS, R F; DA SILVA, I R and STAPE J L (2016). Carbon isotope discrimination and differential drought tolerance in eucalypt clones. Sci. for Piracicaba, 44: 895-903. DOI: dx.doi.org/10.18671/ scifor.v44n112.11.

QIU, G Y; WANG, L; HE, X; ZHANG, X; CHEN, S; CHEN, J and YANG, Y (2008). Water use efficiency and evapotranspiration of winter wheat and its response to irrigation regime in the north China plain. Agric. Water Manage., 148: 1848-1859. http:/ / dx.doi.org/10.1016/j.agrformet.2008.06.010

READ, J and FARQUHAR, G (1991). Comparative studies in Nothofagus (Fagacea). I. Leaf carbon isotope discrimination. Func Eco., 5: 684-695. DOI: $10.2307 / 2389489$

REES, A R (1961). Midday closure of stomata in the oil palm Elaeis guineensis Jacq. J. Exp. Botany, 12:129146. DOI.org/10.1093/jxb/12.1.129.

RIVERA, Y D; MORENO, L; BAYONA, C and ROMERO, H M (2012). Physiological response of oil palm interspecific hybrids (Elaeis oleifera H.B.K. Cortes versus Elaeis guineensis Jacq.) to water deficit. Braz. J. Plant Physiol., 24: 273-280. DOI. 10.1590/ S1677-04202012000400006.

RIVERA, Y D; CAYON, G E and LOPEZ, J E (2013). Physiological and morphological characterization of american oil palms (Elaeis oleifera HBK Cortes) and their hybrids (Elaeis oleifera $\times$ Elaeis guineensis) on the Indupalma plantation. Agron. Colomb., 31: 314-323.

RIVERA, Y D; CUENCA, J C and ROMERO, H $M$ (2016). Physiological responses of oil palm (Elaeis guineensis Jacq.) seedlings under different water soil conditions. Agron. Colomb., 34:163-171. DOI:10.15446/ agron.colomb.v34n2.55568.

SAS INSTITUTE (2002). SAS User's Guide Statistics. Version 9. SAS Institute, Cary. NC.

SENEVIRATNE, S I; CORTI, T; DAVID, E L; HIRSCHI, M; JAEGER, E B; LEHNER, I; ORLOWSKY, B and TEULING, A J ( 2010). Investigating soil moistureclimate interactions in a changing climate: A Review. Earth Sci, Rev., 99: 125 - 161.

SILVA, P A; COSME, V S; RODRIGUES, K C B; DETMANN, K S C; LEAO, F M; CUNHA, R L; FESTUCCI-BUSELLI, R A; DAMATTA, F $\mathrm{M}$ and PINHEIRO, H A (2017). Drought tolerance in two oil palm hybrids as related to adjustments in carbon metabolism and vegetative growth. Acta Physiol. Plant, 39: 58.

SURESH,K;NAGAMANI,C;RAMACHANDRUDU, $\mathrm{K}$ and MATHUR, R K (2010). Gas-exchange characteristics, leaf water potential and chlorophyll a fluorescence in oil palm (Elaeis guineensis Jacq.) seedlings under water stress and recovery. Photosynthetica, 48: 430-436. DOI:10.1007/s11099010-0056-x.

TAIZ, L and ZEIGER, E (2006). Plant Physiology. $4^{\text {th }}$ edition. Sinauer Associates, Inc. 
VILLALOBOS, E; UMANA, C H and CHINCHILLA, Y C (1992). Estado de hidratación de la palma aceitera, en respuesta a la sequia en Costa Rica. Oléagineux, 47: 217-223.

WICKMAN, F E (1952). Variations in the relative abundance of the carbon isotopes in plants. Geochimicaet Cosmochimica Acta, 2: 243-254. https: / / doi.org/10.1016/0016-7037(52)90018-5

WILSON, K B; BALDOCCHI, D D and HANSON, P J (2000). Quantifying stomatal and non-stomatal limitations to carbon assimilation resulting from leaf gaing and drought in mature deciduous tree species. Tree Physiol., 20: 787-797. DOI:10.1093/treephys/ tpu057.

ZONA, D; JANSSENS, I A; AUBINET, M; GIOLI, B; VICCA, S; FICHOT, $S$ and CEULEMANS, R (2013). Fluxes of the greenhouse gases $\left(\mathrm{CO}_{2}, \mathrm{CH}_{4}\right.$ and $\mathrm{N}_{2} \mathrm{O}$ ) above a short-rotation poplar plantation after conversion from agricultural land. Agric. for Meteorol., 169: 100-110. DOI:10.1016/j. agrformet.2012.10.008. 